\title{
Analisis Perhitungan Harga Pokok Produksi dengan Metode Tradisional dan Activity Based Costing (ABC) pada UD. Cella Cake dan Bakery Manado
}

\author{
Jimmy Kamasih ${ }^{1}$ \\ David. P. E. Saerang ${ }^{2}$ \\ Lidya Mawikere ${ }^{3}$ \\ Fakultas Ekonomi dan Bisnis Jurusan Akuntansi \\ Universitas Sam Ratulangi Manado

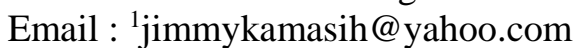

\begin{abstract}
Activity Based Costing System can provide information for the better of cost calculation and can assist management to manage the company efficiently and gain a better understanding on competitive advantages, strengths, and weaknesses of the company. So that with Activity Based Costing can present carefully the information of cost product and accurately to the interests of management and comparing the cost calculation of production by using traditional methods and Activity Based Costing (ABC) at UD. Cella Cake and Bakery Manado. The purpose of this study was to determine the cost calculation of production using traditional methods and Activity Based Costing $(A B C)$. The research method used is descriptive method. The results showed that the cost calculation of production using Activity-Based Costing System provides results that are more expensive than traditional systems on Pizza Chicken Bread, Sausage Bread and donuts. Traditional systems provide greater profit than the Activity-Based Costing system, because the calculations with the traditional system using only one cost driver so make inefficiency costs and generate profit and irrelevant
\end{abstract}

Keywords : Traditional Method, Activity Based Costing, Cost Calculation of Production

\section{PENDAHULUAN}

\section{Latar Belakang}

UD. Cella Cake dan Bakery adalah perusahaan keluarga yang bergerak dalam bidang industri yang mengelola bahan mentah menjadi barang jadi atau yang lebih spesifik lagi adalah suatu industri pengelolaan produk yang menghasilkan roti UD. Cella Cake dan Bakery berlokasi di kota Manado ini memiliki tingkat persaingan yang cukup tinggi, karena telah banyak perusahaan di kota Manado yang bergerak dalam bidang industri yang sama. Diperlukan ketepatan dan kecermatan dalam menghitung dan membebankan biaya sesuai dengan jumlah yang telah dikonsumsi oleh setiap aktivitas pembuatan produk agar dapat memperoleh harga pokok produksi yang akurat.

Salah satu faktor yang sangat penting untuk mencapai tujuan tersebut dalam perusahaan adalah dalam menentukan harga pokok produksi secara akurat karena harga pokok produksi tersebut akan dijadikan dasar dalam penentuan harga jual dan menghitung laba atau rugi perusahaan. Penentuan harga pokok produksi setiap produk 
UD. Cella Cake dan Bakery hanya memasukkan komponen biaya bahan saja. Hal tersebut jelas tidak sesuai dengan perhitungan harga pokok produksi secara tepat.

Ada dua metode perhitungan harga pokok produksi yaitu metode Tradisional dan Activity Based Costing. Perhitungan harga pokok produksi dengan metode Tradisional akan lebih efektif digunakan jika perusahaan hanya memproduksi satu jenis produk saja, akan tetapi jika perusahaan memproduksi lebih dari satu produk maka perusahaan harus memisahkan biaya overhead pabrik untuk masing-masing produk.

Menganalisa penentuan harga pokok produksi perlu diketahui biaya produksi yang terjadi berkaitan langsung dengan proses produksi. Kondisi tersebut akan berpengaruh terhadap penetapan harga jual dan laba yang akan diperoleh perusahaan. Penanggulangan ketidaktepatan harga pokok produksi maka harus diusahakan penggolongan biaya-biaya sesuai dengan fungsi pokok perusahaan. "Analisis Perhitungan Harga Pokok Produksi dengan Metode Tradisonal dan Activity Based Costing (ABC) pada UD. Cella Cake dan Bakery Manado".

\section{Tujuan Penelitian}

Tujuan penelitian ini adalah Untuk mengetahui perhitungan harga pokok produksi dengan menggunakan metode tradisonal dan Activity Based Costing (ABC) pada UD. Cella Cake dan Bakery Manado.

\section{TINJAUAN PUSTAKA Akuntansi Manajemen}

Menurut Statement on Management Accounting No. 2 yang disadur oleh Amin Widjaja Tunggal, (2010:2) mendefinisikan akuntansi manajemen didefinisikan sebagai "Proses identifikasi (atas transaksi), akumulasi (atas transaksi), analisis (atas transaksi yang berhubungan dengan kejadian lain), penyiapan dan interprestasi (atas data), dan komunikasi (kepada manajemen) untuk pemakaian internal dan eksternal.

\section{Akuntansi Biaya}

Akuntansi Biaya adalah proses pencatatan, penggolongan, peringkasan dan penyajian biaya, pembuatan dan penjualan produk dan jasa, dengan cara-cara tertentu, serta penafsiran terhadapnya (Mulyadi, 2012:7).

\section{Harga Pokok Produksi}

Supriyono (2011 : 47) menyatakan harga perolehan atau harga pokok adalah jumlah yang dapat diukur dalam satuan uang dalam bentuk : kas yang dibayarkan, atau nilai aktiva lainnya yang diserahkan atau dikorbankan, atau nilai jasa yang diserahkan atau dikorbankan, atau hutang yang timbul, atau tambahan modal dalam rangka pemilikan barang dan jasa yang diperlukan perusahaan baik pada masa lalu maupun pada masa yang datang (harga perolehan yang akan terjadi).

\section{Activity Based Costing System (ABCS)}

$A B C$ System merupakan sistem informasi biaya yang mengubah cara yang digunakan oleh manajemen dalam pengelolaan bisnis. Jika dalam manajemen tradisional, pengelolaan bisnis didasarkan pada fungsi, dengan $A B C$ System, pengelolaan bisnis diubah menjadi pengelolaan berbasis aktivitas. (Mulyadi, 2012 : 51). 


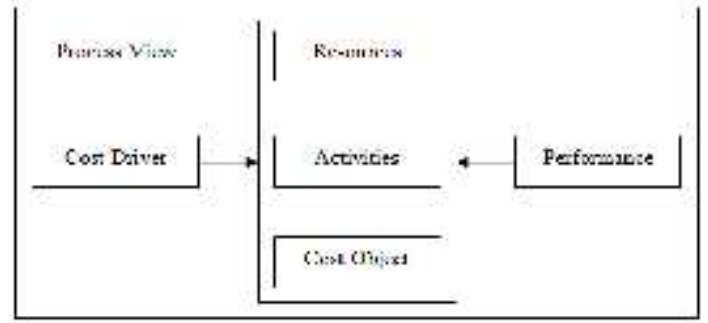

Gamber 2.2 Kousep Dasir $A B C$. Sysiern

Konsep Dasar ABC System yang dikemukakan oleh Hansen dan Mowen (2011, 321) adalah suatu sistem kalkulasi biaya yang pertama kali menelusuri biaya ke aktivitas kemudian ke produk.

\section{Penelitian Terdahulu}

Dilla Lissa Arumsari, Susanto Diamandjojo (2012) dalam penelitiannya mengenai Analisis perhitungan harga Pokok produksi dengan Metode Tradisonal dan Activity Based Costing (ABC) pada PT Usari dengan tujuan untuk melakukan perhitungan harga pokok produksi produk "Majalah Adila, Lembar Kerja Siswa, dan Agenda Migas" dengan menggunakan metode Tradisional dan Activity Based Costing. Hasil penelitiannya harga pokok per unit menunjukkan bahwa harga pokok produksi dengan menggunakan metode Activity Based Costing lebih akurat karena dapat menghemat biaya overhead pabrik sehingga penentuan harga jual menjadi lebih kompetitif.

Akbar (2011) dalam penelitiannya mengenai Analisis Penerapan Metode Activity Based Costing System dalam Penentuan Harga Pokok Kamar Hotel pada Hotel Coklat di Makassar. Tujuannya untuk mengetahui perbandingan besarnya harga pokok kamar hotel, dengan menggunakan metode akuntansi biaya tradisional dan Activity Based Costing System pada Hotel Coklat Makassar. Hasil penelitiannya penggunaan metode Activity Based Costing dalam perhitungan harga pokok kamar akan menghasilkan harga pokok kamar yang akurat, karena biaya-biaya yang terjadi dibebankan pada produk atas dasar aktivitas dan sumber daya yang dikonsumsikan oleh produk dan juga menggunakan dasar lebih dari satu cost driver.

\section{METODE PENELITIAN}

\section{Jenis Penelitian}

Jenis Penelitian merupakan penelitian deskriptif yaitu suatu metode penelitian yang ditujukan untuk mendeskripsikan/menggambarkan fenomena-fenomena yang ada baik fenomena yang bersifat alamiah atau rekayasa manusia (Sukmadinata, 2011 : 88).

\section{Objek Penelitian}

Penelitian ini dilakukan di perusahaan UD. Cella Cake dan Bakery yang terletak di Tikala Ares Kota Manado.

\section{Metode Pengumpulan Data}

\section{Jenis Data}

Jenis data yang digunakan dalam laporan ini adalah:

1. Data Kuantitatif

Data kuantitatif yang digunakan dalam penulisan laporan ini berupa data-data perusahaan yang diukur dalam satuan volume dan satuan uang, antara lain anggaran bahan baku, anggaran biaya overhead pabrik, biaya produksi, laporan laba rugi, neraca, dan lain-lain, 
2. Data Kualitatif

Data kualitatif yang digunakan dalam penulisan laporan ini berupa keterangan dan penjelasan dari pihak perusahaan yang berkaitan dengan metode pengumpulan data penetapan harga pokok persediaan, perhitungan laba, dan lain-lain.

\section{Sumber Data}

Sumber data yang dipakai penulis dalam laporan skripsi ini adalah:

1. Data Primer

Data yang diperoleh langsung dari objek yang akan diteliti (tidak melalui perantara) berupa hasil wawancara langsung dengan karyawan dan juga pimpinan UD. Cella Cake dan Bakery.

2. Data Sekunder

Merupakan data yang dikelompokkan oleh lembaga pengumpul data yang dipublikasikan kepada pengguna data, maupun data yang didapat dari buku dan informasi lainnya maupun kepustakaan.

\section{Teknik Pengumpulan Data}

Teknik yang digunakan dalam pengumpulan data untuk penelitian ini adalah dengan menggunakan cara sebagai berikut :

1. Penelitian kepustakaan (Library research)

Untuk melengkapi data, penulis melakukan penelitian kepustakaan yakni melalui buku-buku dan tulisan ilmiah yang menyangkut masalah yang berhubungan dengan penelitian ini.

2. Penelitian lapangan (Field research)

Merupakan penelitian langsung yang dilakukan di UD. Cella Cake dan Bakery melalui :

a. Wawancara.

Melakukan wawancara langsung dengan pimpinan dan karyawan bagian akuntansi pada UD. Cella Cake dan Bakery untuk memperoleh data yang dibutuhkan.

\section{Metode Analisa Data}

Analisa data yang digunakan dalam penelitian ini adalah metode analisis deskriptif. Sugiyono (2010:105) menyatakan metode analisis deskriptif, yaitu metode penelitian dengan cara mengumpulkan data-data sesuai dengan yang sebenarnya kemudian data-data tersebut disusun, diolah dan dianalisis untuk dapat memberikan gambaran mengenai masalah yang ada. 


\section{Prosedur Penelitian}

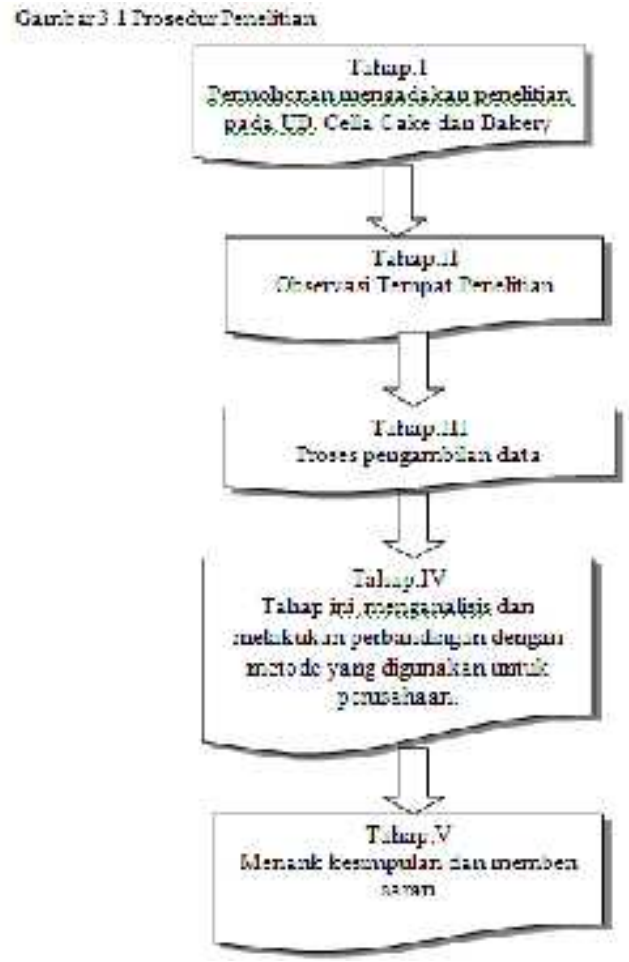

\section{HASIL PENELITIAN DAN PEMBAHASAN}

\section{Gambaran Objek Penelitian}

Perusahaan Cella Cake dan Bakery adalah perusahaan keluarga yang bergerak dalam bidang industri yang mengelola bahan mentah menjadi barang jadi atau yang lebih spesifik lagi adalah suatu industri pengelolaan produk yang menghasilkan roti. Perusahaan ini didirikan pada tanggal 19 Juli 1988 oleh pemiliknya Ny. Sofietje Rangian. Perusahaan ini memperoleh ijin tempat usaha (SITU) dengan nomor 155/18.05P.P.M/IX/1988. Adapun lokasi dari UD. Cella Cake \& Bakery ini terletak di Jalan. Tikala Ares 1 No.6 Manado.

\section{Hasil Penelitian}

Tahel Prodnksi Roti Per Bulan

\begin{tabular}{|c|c|c|}
\hline No. & Jenis Produk & Inmlah Produksi (T'nit) \\
\hline 1. & Koti Coklat $K=j H$ & 6.Coty \\
\hline$?$ & Roti Kacsus, & 600 in \\
\hline 3. & Roti Pizza Aym & 5.000 \\
\hline 4 & Roti: Sosis & 5000 \\
\hline & Donat & 8.000 \\
\hline & Jumlah & 30000 \\
\hline
\end{tabular}

Sumber: UD. Cella Cabz is Baikor.

Tabel di atas menjelaskan bahwa jumlah produksi roti yang diproduksi perusahaan UD. Cella Cake \& Bakery setiap bulannya berjumlah 30.000 unit. 
Tabel pemakaian Bahan Baku

\begin{tabular}{|c|c|c|c|}
\hline No. & $\begin{array}{l}\text { Jenis Produk } \\
\text { Knti C.sklar Keau } \\
\text { Knti Kacang. }\end{array}$ & $\begin{array}{c}\text { Jumlah Produksi } \\
\text { (Unit) } \\
600 \% \\
600 \%\end{array}$ & $\begin{array}{c}\text { Bahan Baku } \\
\text { (Rp) } \\
10.10)+0 \% \\
10+200 \%\end{array}$ \\
\hline 3. & Reti Pirza Avam & 5.000 & 10.350 .000 \\
\hline 1 & Roti Sosis & 501 & 756000 \\
\hline 5. & Donat & 8.000 & 7.500 .000 \\
\hline & Jus:liath & 30.000 & 22.100 .000 \\
\hline
\end{tabular}

Surulet. UD. Cella Cake $\&$ Bakery

Berdasarkan tabel di atas dapat diketahui bahwa jumlah biaya bahan baku yang digunakan untuk membuat roti coklat keju merupakan biaya bahan baku yang paling tinggi yaitu sebesar Rp.10.500.000 kemudian untuk biaya bahan baku roti pizza ayam yaitu sebesar Rp.10.350.000 sedangkan roti kacang mempunyai biaya bahan baku yang lebih rendah daripada roti coklat keju dan pizza ayam yaitu sebesar Rp.10.000.000 selanjutnya untuk roti sosis biaya bahan bakunya adalah sebesar Rp.9.500.000 dan donat adalah dengan biaya bahan baku terendah yakni Rp.7.500.000 per bulan.

Tabel Biaya Tenaga Kerja Langsung per bulan

\begin{tabular}{|c|c|c|c|}
\hline Tenis Produk & $\begin{array}{c}\text { Tumlah } \\
\text { Produksi } \\
\text { (Unit) }\end{array}$ & $\begin{array}{c}\text { Tpah/Tunit } \\
\left(R_{\Gamma}\right)\end{array}$ & $\begin{array}{c}\text { Riays Tenaga } \\
\text { Kerija } \\
\text { Langsung (Rp) }\end{array}$ \\
\hline I. Kuli Cuklat Keju & 6.010 & 300 & 1.800 .000 \\
\hline 2. Roti Katan: & 6.000 & 300 & 1.800 .000 \\
\hline 3. Ruli PicLA Ayau & 5.000 & 300 & 1.500 .000 \\
\hline 4. Roti Sosis & 5.000 & 300 & 1.500 .000 \\
\hline 5. Donat & 8.000 & 300 & 2.400 .000 \\
\hline Jumlah & 81000 & & 9000200 \\
\hline
\end{tabular}

Berdasarkan tabel di atas dapat dilihat bahwa biaya tenaga kerja langsung untuk roti coklat keju dan kacang adalah sama yaitu Rp.1.200.000, kemudian roti pizza ayam dan sosis juga sama untuk tenaga kerja langsung yakni Rp.750.000 per bulan.

Tabel Biaya overhead pada UD. Cella Cake \& Bakery Manado

\begin{tabular}{|c|c|c|}
\hline No. & Jenis Biaya & Total Biaya (Rp) \\
\hline 1 & Bahan penbanlu & 10.000 .000 \\
\hline 2 & Iistrik & 2.000 .000 \\
\hline 3 & Biaya tenag a kerja tal: langsung & 1.000 .000 \\
\hline 4 & Biaya penelifaran bangurat & 500.000 \\
\hline 5 & Biaya pemeliharaan mesin & 350.000 \\
\hline G & Biaya peny uzulan bangunan & 300.000 \\
\hline 7 & Biaya peryusutan Mesin & 100.000 \\
\hline 8. & Biaya pemasaran & 250.000 \\
\hline & Jumlah & 11.500 .000 \\
\hline
\end{tabular}

Sunber: UD. Cella Cake \& Bakeny 


\section{Pembahasan}

\section{Perhitungan Harga Pokok Produksi dengan Sistem Tradisional pada UD. Cella}

\section{Cake \& Bakery}

Salah satu cara yang biasa digunakan untuk membebankan Biaya Overhead Pabrik pada produk adalah dengan menghitung tarif tunggal dengan menggunakan Cost Driver berdasar unit. Perhitungan Biaya Overhead Pabrik dengan tarif tunggal terdiri dari dua tahap. Pembebanan biaya tahap pertama yaitu biaya overhead pabrik diakumulasi menjadi satu kesatuan untuk keseluruhan pabrik. Tarif tunggal dihitung dengan menggunakan dasar pembebanan biaya berupa jam mesin, unit produk, jam kerja dan sebagainya. Pembebanan biaya tahap kedua biaya overhead Pabrik dibebankan ke produk dengan mengalikan tarif tersebut dengan biaya yang digunakan masing-masing produk 1. Tahap pertama

Tahap pertama yaitu biaya overhead pabrik diakumulasi menjadi satu kesatuan untuk keseluruhan pabrik dengan menggunakan dasar pembebanan biaya berupa unit produk. Perhitungan tarif tunggal berdasarkan unit produk dapat disajikan sebagai berikut:

Tarif tunggal berdasarkan unit produk

$$
\begin{gathered}
=\text { Rp. } 14.500 .000 \\
=\quad \text { Rp. } 4800 \text { unit } \\
=\quad 43 \text { /unit }
\end{gathered}
$$

\section{Tahap kedua}

Tahap kedua yaitu biaya overhead pabrik dibebankan ke produk dengan mengalikan tarif tersebut dengan biaya yang digunakan masing-masing produk. Perhitungan harga pokok produksi dengan sistem tradisional masing-masing produk

\begin{tabular}{|c|c|c|c|}
\hline \multicolumn{4}{|c|}{ Rod Collat Keju } \\
\hline Flemien Riaya & Rixy a Tuial (Rj) & .Tumlah (Tinii) & Biayz Prranii \\
\hline Diaya LItama & 22.300 .000 & 6.000 & 2.030 \\
\hline Biaya Overheać Pabrk= & 2.899 .530 & 6.000 & 183.33 \\
\hline \multicolumn{3}{|c|}{ Jumlah } & 2.533 .33 \\
\hline \multicolumn{4}{|c|}{ Rati Tacang } \\
\hline Elemen Biaya & Biays Total (Rp) & Junlah (Unit) & Biaya Per Unit \\
\hline $\operatorname{Bizy} 2 \mathrm{U} .2 \mathrm{tr} 2$ & 11800.200 & 6.000 & 1.966 .66 \\
\hline Jiaya Urerheac l'abzk- & 2.899580 & 6.000 & 483.33 \\
\hline \multicolumn{3}{|c|}{ Jumlah } & $2.445 .9 \%$ \\
\hline \multicolumn{4}{|c|}{ Roti Pixxa Ayam } \\
\hline Elenen Hiaya & Biara lotal $\left(\mathrm{K}_{\mathrm{P}}\right)$ & Junilah (Unit) & Diaya l'er Unit \\
\hline Bizy 2 U. 2412 & 11850.200 & 5.000 & 1.975 \\
\hline $\begin{array}{l}\text { Jiaya Urerheac l'abnk- } \\
483.33 . x 3.002\end{array}$ & 916.850 & 5.000 & 283.33 \\
\hline \multicolumn{3}{|c|}{ Junlah } & 2.154 .33 \\
\hline \multicolumn{4}{|c|}{ Roti Sosis } \\
\hline F.Iemen Hiaya & Iliậa Fotal $\left\langle R_{\mathrm{P}}\right\rangle$ & Inmilah (Ilmit) & Hiaya I'er Init \\
\hline Biaya U:am & if 000.000 & 5.000 & $2.200^{\circ}$ \\
\hline $\begin{array}{l}\text { 3ixy z OvelutacPabil- } \\
483.33 . \pi 5.000\end{array}$ & 916.650 & 5.000 & 183.333 \\
\hline \multicolumn{3}{|c|}{ Jumlah } & 2.383 .33 \\
\hline \multicolumn{4}{|c|}{ Donat } \\
\hline Eleacen Biay & Bixy a Tutal ( $\left.\mathrm{R}_{\mathrm{P}}\right)$ & Jumlah (Unii) & Bixy x Per Tnit \\
\hline Jjaya U:amı & 9900.000 & 3.000 & 1.237 .2 \\
\hline $\begin{array}{l}\text { Bizy 2 Ovelhtacipabil- } \\
483.33 \times 8.000\end{array}$ & $\therefore 750000$ & 8.200 & $2: 3.35$ \\
\hline \multicolumn{3}{|c|}{ Jumlah } & 1.456 .25 \\
\hline
\end{tabular}
disajikan dalam tabel sebagai berikut:

Tabel Pertilungan Harna Pukok Produksi dengan Sistem Tradisiunal

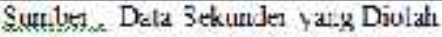


Hasil perhitungan harga pokok produksi per unit dengan sistem tradisional pada UD.Cella Cake \& Bakery diperoleh hasil harga pokok produksi untuk Roti coklat keju adalah sebesar Rp 2.533.33/unit, Roti kacang sebesar Rp.2.449.99/unit, Roti pizza ayam sebesar Rp 2.158.33/unit, Roti sosis sebesar Rp2.383.33/unit dan Roti Keju sebesar Rp 1.453.25 /unit.

Perhitungan Harga Pokok Produksi dengan Activity-Based Costing System pada UD. Cella Cake \& Bakery

a. Tahap pertama

Tahap pertama menentukan harga pokok produksi berdasar Activity- Based Costing System adalah menelusuri biaya dari sumber daya keaktivitas yang mengkonsumsinya. Tahap ini terdiri dari:

1) Mengidentifikasi dan menggolongkan aktivitas

Pada UD. Cella Cake \& Bakery aktivitas dapat digolongkan menjadi empat level aktivitas. Rincian penggolongan aktivitas-aktivitas dapat dilihat pada Tabel sebagai berikut:

Tabel Klasifikasi Biaya ke Dalam Berbagai Alitivitas pada UD.Cella Cake \&

Bukery Setiap Bulau

\begin{tabular}{|c|c|c|}
\hline \multirow[t]{3}{*}{ Aktivitas Lerel Unit } & $\begin{array}{l}\text { Komponen BOP } \\
\text { Biaya bahan pernbantu }\end{array}$ & $\begin{array}{l}\text { Jumlah (Rp) } \\
10.000 .000\end{array}$ \\
\hline & Biaya energ1 & 2.0000 .000 \\
\hline & $\begin{array}{l}\text { Biayn penyusutan mesir. } \\
\text { Biaya tenagz kerja tak langsung }\end{array}$ & $\begin{array}{r}100.000 \\
1.000 .000\end{array}$ \\
\hline Aktivitas Level Batch & Biaya pemeliharaan masin & 350000 \\
\hline Aktivitas Level Produk & Biaya pemasaran & 250.000 \\
\hline \multirow[t]{2}{*}{ Aktivitas Lovel Fasilitas } & Biaya ferncliharaan bangunan & 500.000 \\
\hline & Biaya penyusutan banguran & 300.000 \\
\hline \multicolumn{2}{|r|}{ Jumlah } & 14.500 .000 \\
\hline
\end{tabular}

Berdasarkan tabel diatas dapat dijelaskan tiap level aktivitas yang dapat diidentifikasi meliputi:

a) Aktivitas Unit Level (Unit-Level Activities), Aktivitas ini terjadi berulang untuk setiap unit produksi dan konsumsinya seiring dengan jumlah unit yang diproduksi. Jenis aktivitas ini meliputi pemakaian bahan pembantu, aktivitas pemakaian energi, dan aktivitas penyusutan mesin.

b) Aktivitas Batch Level (Batch-Level Activities) Merupakan jenis aktivitas yang dikonsumsi oleh produk berdasarkan jumlah batch produk yang diproduksi dan aktivitas penyebab biaya ini terjadi berulang setiap satu batch (kelompok). Aktivitas yang termasuk dalam level ini adalah biaya tenaga kerja tak langsung dan biaya pemeliharaan mesin.

c) Aktivitas Produk Level (Product-Level Activities) Merupakan jenis aktivitas yang dikonsumsi produk yang dihasilkan oleh aktivitas tersebut. Aktivitas ini dilakukan untuk mendukung produksi tiap produk yang berbeda. Aktivitas yang masuk dalam level ini aktivitas pemasaran.

d) Aktivitas Fasilitas Level (Facility-Level Activities) Merupakan jenis aktivitas yang dikonsumsi oleh produk berdasarkan fasilitas yang dinikmati oleh produk. Aktivitas 
ini berkaitan dengan unit, batch maupun produk. Jenis aktivitas ini meliputi pemeliharaan bangunan dan penyusutan bangunan,

2) Menghubungkan berbagai biaya dengan berbagai aktivitas.

a) Aktivitas pemakaian bahan pembantu dalam proses produksi menkonsumsi biaya bahan pembantu.

b) Aktivitas pemakaian energi listrik dalam proses produksi menkonsumsi biaya listrik.

c) Aktivitas penyusutan mesin mengkonsumsi biaya penyusutan mesin.

d) Aktivitas penyusutan bangunan mengkonsumsi biaya penyusutan bangunan.

e) Aktivitas pemakaian tenaga kerja tak langsung mengkonsumsi biaya tenaga kerja tak langsung.

f) Aktivitas reparasi dan pemeliharaan mesin mengkonsumsi biaya pemeliharaan mesin.

g) Aktivitas reparasi dan pemeliharaan bangunan mengkonsumsi biaya pemeliharaan bangunan.

h) Aktivitas pemasaran dalam proses produksi mengkonsumsi biaya pemasaran.

3) Menentukan Cost Driver yang tepat untuk masing-masing aktivitas

Setelah aktivitas-aktivitas diidentifikasi sesuai dengan levelnya, langkah selanjutnya adalah mengidentifikasi Cost Driver dari setiap biaya. Pengidentifikasian ini dimaksudkan dalam penentuan tarif per unit Cost Driver. Data Cost Driver pada setiap produk dapat dilihat pada Tabel berikut ini:

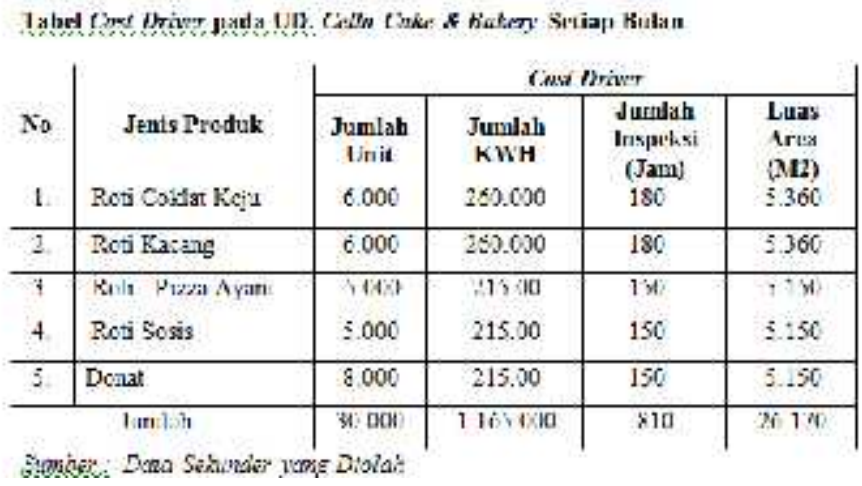

4) Penentuan kelompok-kelompok biaya yang homogeny (Homogeneous Cost Pool). Pembentukan Cost Pool yang homogen dimaksudkan untuk merampingkan pembentukan Cost Pool yang terlalu banyak, karena aktivitas yang memiliki Cost Driver yang berhubungan dapat dimasukkan ke dalam sebuah Cost Pool dengan menggunakan salah satu Cost Driver yang dipilih. Aktivitas yang dikelompokkan dalam level unit dikendalikan oleh dua Cost Driver yaitu jumlah unit produksi dan jumlah KWH. Aktivitas yang dikelompokkan dalam batch level dikendalikan oleh satu Cost Driver yaitu jam inspeksi. Aktivitas yang dikelompokkan dalam level produk dikendalikan satu CostDriver yaitu jumlah unit produksi, sedangkan aktivitas yang dikelompokkan dalam level fasilitas dikendalikan oleh satu CostDriver yaitu luas area yang digunakan. Rincian Cost Pool yang homogen pada UD.Cella Cake \& Bakery dapat dilihat pada Tabel sebagai berikut: 
Tahel Cost Phol Homngen parla ITh. Cella Cake \& Bakpy

\begin{tabular}{|c|c|c|c|}
\hline $\begin{array}{l}\text { Cost Pool } \\
\text { Homogen }\end{array}$ & Aktifitas BOP & Cost Driver & Level aktivitas \\
\hline \multirow[t]{2}{*}{$P \cap I 1$} & Aktivitas hahan pemhant: & Tumlah T Jnit & Irit T avel \\
\hline & Aktivitas penyrusutar. mesin & Jumlah Unit & Urit Lavel \\
\hline Pool 2 & Aktivilas pernakdian listr ik & $\mathrm{KWH}$ & Util Lavel \\
\hline \multirow[t]{2}{*}{$\mathrm{PCOl} 3$} & $\begin{array}{l}\text { Aktivitas ter.aga herja tak } \\
\text { Langsung }\end{array}$ & am isrpeksi & Batch Level \\
\hline & $\begin{array}{l}\text { Nktivitas perrelihnraan } \\
\text { Mcsir. }\end{array}$ & In impeksi & Batch Level \\
\hline Ponl 4 & Aktivitas perrasatan & Thit Prodink & Produk Tevel \\
\hline \multirow[t]{2}{*}{ Pools } & $\begin{array}{l}\text { Aktrutas perreliharaan } \\
\text { Brngunen }\end{array}$ & Luas area & Fasilitas Level \\
\hline & $\begin{array}{l}\text { Aktivitas penpusutar: } \\
\text { Banguelen }\end{array}$ & Luas area & F asilitas Level \\
\hline
\end{tabular}

Saposeri, Lata Sekunder yang Diolah

5) Penentuan tarif kelompok (Pool Rate)

Setelah menentukan Cost Pool yang homogen, kemudian menentukan tarif per unit Cost Driver. Tarif kelompok (Pool Rate) adalah tarif Biaya Overhead Pabrik per unit Cost Driver yang dihitung untuk suatu kelompok aktivitas. Tarif kelompok dihitung dengan rumus total Biaya Overhead Pabrik untuk kelompok aktivitas tertentu dibagi dengan dasar pengukur aktivitas kelompok tersebut. Tarif per unit Cost Driver dapat dihitung dengan rumus sebagai berikut:

Tarif BOP per kelompok Aktivitas $=$

BOP kelompok Aktivitas Tertentu

Driver Biaya 
Tabel I'ool Rate aktivitas level unit pada

\begin{tabular}{|c|c|c|}
\hline Cost Pool & Elemen BOP & Jumlah (Rp) \\
\hline \multirow[t]{2}{*}{ Pool 1} & Bieva bahar pombantu & 10.000 .000 \\
\hline & Пiаva penynsutan mesin & 100000 \\
\hline $\begin{array}{l}\text { Tum ulan lviayt } \\
\text { Jam unit preduksi } \\
\text { Pool Rate }\end{array}$ & & $\begin{array}{c}10100000 \\
30.000 \text { unit } \\
\text { Rp } 336.57 / \text { unit }\end{array}$ \\
\hline Paoi 2 & Biaya energi & 2.000 .000 \\
\hline $\begin{array}{l}\text { Tumlah bixya } \\
\text { Jumlah KWH } \\
\text { Poot Rate } 2\end{array}$ & & $\begin{array}{c}2 \cos 0.00 \\
1.165 .000 \\
\operatorname{Rp} 1.71 \text {, nuit }\end{array}$ \\
\hline \multirow{2}{*}{ Paoi 3} & Biàya tenaga kerja tak langsung & 1.000 .000 \\
\hline & Bizya pemeliharaan mesin & 350.000 \\
\hline $\begin{array}{l}\text { Tamlah hiaya } \\
\text { Jam ir.spcksi } \\
\text { Pool Rate } 3\end{array}$ & & $\begin{array}{c}1750000 \\
810 \mathrm{jam} \\
\mathrm{Rp}: 1.665 .57\end{array}$ \\
\hline Paoi 4 & Bizya pemasaran & 250.000 \\
\hline $\begin{array}{l}\text { Junlah biaya } \\
\text { Unit procuik } \\
\text { pool Rate } 4\end{array}$ & & $\begin{array}{c}250.000 \\
30.000 \\
\operatorname{Re} 8.33 / \text { Urit }\end{array}$ \\
\hline \multirow[t]{2}{*}{ Poois } & Bisya pomsliharaan benguran & 500.000 \\
\hline & Biava penyusutan jangunan & 300.000 \\
\hline $\begin{array}{l}\text { Juralah biaya } \\
\text { Luas arca } \\
\text { Pool Rate } 5\end{array}$ & & $\begin{array}{c}800.000 \\
26.170 \\
\text { Rp } 30.56 \text { unit }\end{array}$ \\
\hline
\end{tabular}

Sumber, Data Sehwinder yairg Dioiair

\section{Prosedur Tahap Kedua}

Tahap kedua menentukan Harga Pokok Produksi berdasar aktivitas adalah membebankan tarif kelompok berdasarkan CostDriver. Biaya untuk setiap kelompok Biaya Overhead Pabrik dilacak ke berbagai jenis produk. Biaya Overhead Pabrik ditentukan dari setiap kelompok biaya ke setiap produk dengan rumus sebagai berikut:

Biaya yang dibebankan $=$ Tarif kelompok $\mathrm{X}$ unit cost driver yang digunakan

Berdasarkan pembebanan Biaya Overhead Pabrik yang telah dilakukan, maka perhitungan Harga Pokok Produksi dengan menggunakan Activity-Based Costing System pada UD.Cella Cake \& Bakery setiap bulan dapat disajikan pada Tabel sebagai berikut: 
Tabel Perhitungan Harga Pokok Produksi dengan Activity-Based Costing System pada UD. Cello Cake \& Bakery

\begin{tabular}{|c|c|c|c|c|c|}
\hline Keterangan & $\begin{array}{l}\text { Roti } \\
\text { Coklat } \\
\text { Keju } \\
\left(\mathbf{R p}_{\mathbf{p}}\right)\end{array}$ & $\begin{array}{c}\text { Roti } \\
\text { Kacang } \\
\text { (Rp) }\end{array}$ & $\begin{array}{c}\text { Roti Pizza } \\
\text { Ayam } \\
\text { (Rp) }\end{array}$ & $\begin{array}{l}\text { Roti Sosis } \\
\text { (Rp) }\end{array}$ & $\begin{array}{l}\text { Donat } \\
\text { (Rp) }\end{array}$ \\
\hline EDD & 10.500 .000 & 10.000 .000 & 10.350 .000 & 9.500 .000 & 7.505 .000 \\
\hline DTKL & 1.800 .000 & 1.800 .000 & 1.500 .000 & 1.500 .000 & 2.400 .000 \\
\hline $\begin{array}{l}\text { BOP } \\
\text { (Perubatan) }\end{array}$ & 2.381 .001 & 2.381 .001 & 2.347 .234 & 2.347 .234 & 3.382 .234 \\
\hline HPP & 14.681 .001 & 14.181 .001 & 14.197 .234 & 13.347 .234 & 13.282 .234 \\
\hline Unit Produksi & 0.000 & 6.000 & 5.000 & 5.000 & 5.000 \\
\hline $\begin{array}{l}\text { HPP Per Unit } \\
\text { Pembulatan) }\end{array}$ & 2.447 & 2.363 & 2.840 & 2.670 & 1.660 \\
\hline
\end{tabular}

Sumber: Nota Soztinder yang Dolah

Berdasarkan hasil perhitungan Harga Pokok Produksi per unit roti setiap bulan dengan menggunakan Activity-Based Costing System diperoleh hasil Harga Pokok Produksi untukRoti Coklat keju adalah sebesar Rp 2.447/unit, Roti kacang sebesar Rp 2.363/unit, Roti Pizza Ayam sebesar Rp 2.840/unit, Roti Sosis sebesar Rp 2.670/unit dan Donat sebesar Rp 1.660/unit.

Perbandingan Sistem Tradisional dengan Activity-Based Costing System dalam menentukan Harga Pokok Produksi.

Perbandingan Harga Pokok Produksi Sistem Tradisional dengan Activity- Based Costing System pada UD. Cella Cake \& Bakery dapat dilihat pada Tabel sebagai berikut:

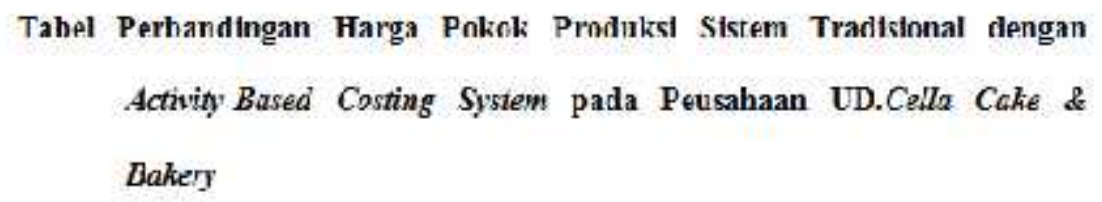

\begin{tabular}{|c|c|c|c|c|c|}
\hline No. & Jenis Produk & $\begin{array}{c}\text { Sistem } \\
\text { Tradisional } \\
\text { (Rp) }\end{array}$ & $\begin{array}{l}\text { Sistem } \\
\text { ABC } \\
\text { (Kp) }\end{array}$ & $\begin{array}{c}\text { Selisih } \\
\text { (Rp) }\end{array}$ & Nilai Kondisi \\
\hline I & Roti Coklat Kej1: & 2533 & 2477 & -55 & - \\
\hline 2. & Rcti Kacang & 2.450 & 2.363 & -37 & - \\
\hline 3 & Roti Piт7a Aysm & 2160 & 2840 & +680 & Merrost \\
\hline 4. & Roti Sosis & 2.383 & 2.670 & +337 & Chancost \\
\hline 5. & Dunal & 1.450 & 1.660 & +204 & Overrcasi \\
\hline
\end{tabular}

Sumbor: UD. Colia Caks \& Bakny

Dari hasil tersebut jika dibandingkan dengan sistem tradisional, maka ActivityBased Costing System memberikan hasil yang lebih besar untuk produk Roti Pizza Ayam, Roti Sosis dan Donat. Selisih untuk Roti Pizza Ayam Rp 680/unit, Roti Sosis Rp 337/unit dan Donat Rp 204/unit. 


\section{PENUTUP}

\section{Kesimpulan}

Dari hasil penelitian dan pembahasan di atas, maka dapat ditarik kesimpulan sebagai berikut :

1. Perhitungan harga pokok produksi menggunakan Activity-Based Costing System memberikan hasil yang lebih mahal dari sistem tradisional adalah pada Roti Pizza Ayam, Roti Sosis dan Donat. Sistem tradisional memberikan perhitungan laba yang lebih besar dibandingkan dengan sistem Activity-Based Costing, dikarenakan perhitungan dengan sistem tradisional hanya menggunakan satu cost driver sehingga banyak terjadi distorsi-distorsi biaya dan menghasilkan perhitungan laba yang tidak relevan.

2. Perbedaan yang terjadi antara harga pokok produksi dengan menggunakan sistem tradisional dengan Activity-Based Costing System disebabkan karena pembebanan biaya overhead Pabrik pada masing-masing produk. Pada Sistem Tradisional biaya pada masing-masing produk hanya dibebankan pada satu Cost Driver saja. Akibatnya cenderung terjadi distorsi pada pembebanan biaya overhead pabrik. Pada metode ActivityBased Costing System, biaya overhead pabrik pada masing-masing produk dibebankan pada banyak Cost Driver, sehingga Activity-Based Costing System mampu mengalokasikan biaya aktivitas ke setiap jenis produk secara tepat berdasarkan konsumsi masing-masing aktivitas.

\section{Saran}

Berdasarkan hasil penelitian dan pembahasan di atas, maka penulis memberi saran sebagai berikut :

1. Harga pokok produksi pada UD. Cella Cake \& Bakery dengan Activity Based-Costing System menampakkan hasil yang relatif lebih besar daripada harga pokok produksi dengan sistem tradisional, namun sebaiknya UD. Cella Cake \& Bakery mengevaluasi kembali sistem pembebanan biayanya dalam menentukan harga pokok produksi karena harga pokok produksi akan mempengaruhi posisi produk di pasar.

2. Pihak manajemen sebaiknya mulai mempertimbangkan perhitungan harga produksi dengan menggunakan Activity Based-Costing System dengan tetap mempertimbangkan faktor-faktor eksternal yang lain seperti harga pesaing dan kemampuan masyarakat. 